\title{
Revision of the species complex Amidostomum acutum (Lundahl, 1848) (Nematoda: Amidostomatidae)
}

\author{
Katarzyna M. Kavetska • Katarzyna Królaczyk • \\ Agata Stapf • Wilhelm Grzesiak • Elżbieta Kalisińska • \\ Bogumila Pilarczyk
}

Received: 7 October 2010 /Accepted: 13 December 2010/Published online: 14 January 2011

(C) The Author(s) 2011. This article is published with open access at Springerlink.com

\begin{abstract}
Most available literature indicates that the most dominant nematode in Anatinae is a cosmopolitan species Amidostomum acutum (Lundahl, 1848). However, studies on wild duck helminthofauna in northwestern Poland suggest that these birds are attacked by not one but three different parasite species, previously described as a single species. Hence the aim of this study was the redescription of the species complex Amidostomum acutum, conducted on a representative sample of parasites and their hosts. The study material consisted of 6,430 nematode individuals, isolated from the digestive tracts of 1,005 wild ducks, representing 17 species. Unsupervised classification was performed using a Kohonen artificial neural network. The analysis confirmed
\end{abstract}

K. M. Kavetska $(\square) \cdot$ K. Królaczyk $\cdot$ A. Stapf

Laboratory of Biology and Ecology of Parasites,

West Pomeranian University of Technology,

Judyma Str. 20,

71-466 Szczecin, Poland

e-mail: katarzyna.kavetska@zut.edu.pl

W. Grzesiak

Laboratory of Biostatistics,

West Pomeranian University of Technology,

Judyma Str. 12 ,

71-466 Szczecin, Poland

E. Kalisińska

Department of Biology and Medical Parasitology,

Pomeranian Medical University,

Powstańców Wielkopolskich Av. 72,

70-111 Szczecin, Poland

B. Pilarczyk

Department of Animal Reproduction Biotechnology and

Environmental Hygiene,

West Pomeranian University of Technology,

Judyma Str. 20

71-466 Szczecin, Poland the division of nematodes into three groups corresponding to three species, both for males and females. Taking into account the qualitative characteristics of the parasites, one can $100 \%$ accurately identify these species. The three groups of parasites were also significantly different in their ecology, manifested in their distinct host specificity.

\section{Introduction}

Nematodes from the genus Amidostomum (Railliet and Henry 1909) are the most frequently quoted parasites of birds associated with aquatic environments in the Palearctic (Czapliński 1962; Baruš et al. 1978; Ryšav et al. 1982; Anderson 2000; Kavetska 2006, 2008; Pojmańska et al. 2007; Atkinson et al. 2008). These parasites live under the chitinous layer of the gizzard, feeding on the blood of the host, and at a high intensity of infection can cause mass deaths (Borgsteede et al. 2005, 2006; Thieltges et al. 2006; Kats 2007).

In Europe, there are six species of this genus, i.e. Amidostomum acutum (Lundahl, 1848), Amidostomum anseris (Zeder 1800), Amidostomum Cygni (Wehr 1933), Amidostomum fulicae (Rudolphi 1819), Amidostomum henryi (Skrjabin 1915), and Amidostomum spatulatum (Baylis 1932). In ducks (Anatinae), Amidostomum acutum occurs almost exclusively (Czapliński 1962; Baruš et al. 1978; Ryšav et al. 1982; Pojmańska et al. 2007, http:// www.faunaeur.org). Research on the helminthofauna of wild Anatinae, conducted for more than 10 years at the Laboratory of Biology and Ecology of Parasites, West Pomeranian University of Technology, suggests that Amidostomum acutum (Lundahl, 1848) is in reality a species complex with three morphologically and ecologically distinct species: Amidostomoides acutum (Lundahl, 1848), Amidostomoides petrovi (Shakhtahtinskaya 1956), and 
Amidostomoides monodon (Linstow, 1882) (Lomakin 1991). This suggestion, based on a much more modest material, was presented in the earlier work of our team (Kavetska 2005a, b, c, 2006, 2008; Kavetska et al. 2008a, b). It is possible that these parasites also have different development cycles (so far only the life cycle of the Amidostomum acutum has been studied; Zajiček 1964), and the recognition of these cycles may be crucial for the protection of many bird species.

Therefore, it seems necessary to make a final revision of the species Amidostomum acutum (Lundahl, 1848) through the confirmation of the hypothesis on the existence of species-level differences of three morphological and ecological forms: Amidostomoides acutum, Amidostomoides monodon, and Amidostomoides petrovi, carried out on a much greater range of subjects than in our previous work and supported by appropriate statistical analysis. For this purpose, a Kohonen artificial neural network was used as a basic type of self-organizing network. Using this network, the individual specimens of nematodes that were similar to one another in terms of morphology, were grouped according to their morphological characteristics. With an a priori assumption of a three-species distribution of the examined nematodes, an analysis of discriminant analysis was performed in order to verify whether the applied division coincides with the clustering of the examined parasites into three species.

\section{Materials and methods}

The study material consisted of 6,430 nematodes from the subfamily Amidostomatinae (Travassos, 1919) which were isolated from the digestive tracts of 1,005 wild ducks (Anseriformes: Anatidae) from north-western Poland. Host species represented 17 species from eight genera belonging to three tribes: Anatini $(n=225)$, Aythyini $(n=413)$, and Mergini $(n=367)$. The study, conducted during the years 1999-2009, included Polish game species (mallard, teal, tufted duck, and pochard, a total of 471 individuals) and protected species (other duck species, including 534 birds), found dead in fishing nets. The isolated nematodes were fixed and stored in $70 \%$ ethanol, and scanned in glycerol or $80 \%$ lactic acid.

Morphometric analysis involved a group of 144 randomly selected nematodes from the subfamily Amidostomatinae (71 males and 73 females), isolated from six species of ducks: mallard, common goldeneye, greater scaup, tufted duck, common scoter, and eider.

\section{Unsupervised classification}

In order to carry out the unsupervised classification for male nematodes using a Kohonen artificial neural network, we used 13 variables describing their morphometry. The morphometric indices were normalized by rescaling their numerical values to the interval $[0,1]$. These cases were the input layer of a neural network composed of 13 neurons. The output layer consisted of nine radial neurons forming the topology of $3 \times 3$ neurons. Network learning was based on randomly selected 61 cases and ten validation cases which were used to control the stability of the network error in the process of learning. The learning used a Kohonen algorithm (Kohonen 1989; Haykin 2009) according to which the nodes from the surroundings of the winning neuron are matched by a linear combination of the input vector $x_{n}\left(x_{n 1}, x_{n 2} \ldots x_{n j}\right)$ and a current weight vector $W_{n j}$ according to the formula:

$W_{n j}^{k+1}=W_{n j}^{k}+\eta \cdot f \cdot\left(x_{n}-W_{n j}^{k}\right)$,

where:

$W_{n j}$-weight vector $\left[w_{1 j}, w_{2 j}, w_{n j}\right]$, connected to the neuron $j$, output; $\eta$, learning rate; which was assumed to be decreasing from the initial value 0.3 to a final value of 0.01 , $f$, neuron neighborhood function with a defined center, with a value 1 if the Euclidean distance between the weight vectors of the winner neuron and the $n$th neuron meets the criterion:

$\sqrt{\sum_{i}^{N}\left(x_{n}-W_{n j}\right)^{2}} \leq \lambda$,

where:

$N$, number of inputs in the neural network, $k$, the number of a training epoch, $\lambda$, radius of the neighborhood with a value decreasing over the time of learning. For the remaining neurons, the function assumes a value 0 (Samarasinghe 2006; Osowski 1996).

Network learning was carried out for 3,500 epochs. During each epoch, the whole learning set was presented to the network, and then used to modify the weights $w_{j}$ of the network threshold value. Learning and validation cases were combined from epoch to epoch. Neighborhood range included rows and adjacent columns in the matrix of evenly distributed neurons $(3 \times 3)$.

The number of wins for each neuron is presented on a topological map (Kohonen network radial layer, where each neuron was assigned the previously proposed labels corresponding to individual species of parasites).

For female respondent nematodes, the method of the Kohonen neural network preparation was similar, except that the input vector included 18 neurons, i.e. equal to the number of variables describing their morphometry. In learning, 63 learning cases and ten validation cases were used. The number of epochs was increased to 5,000. The remaining network parameters were the same as for the 
males. The preparation and analysis of artificial neural networks was performed using an SNN 4.0F program (Statistica Neural Network 1998).

\section{Discriminant analysis}

Next, discriminant analysis was performed for males and females, assuming the previously proposed split into three species of parasites. A percentage of correct classifications for the various species of nematodes were shown on the classification matrix. Variables with the greatest discriminatory contribution were isolated based on the value of the tolerance coefficient - indicating the redundancy of a given variable, significance of $F$ statistics calculated on the basis of Wilks' lambda coefficient, which determines the discriminative power of individual variables (Morrison 1990).

$\Lambda_{m}=\prod_{i=m+1}^{t}\left(1-r_{d}^{2}\right)$

where:

$\Lambda_{m}$-Wilks' lambda coefficient ( $m=1,2 . ., t-1$, where $t$ the rank of matrix of the inter-group sum of squares), $r^{2}{ }_{d}$-coefficient of determination between the canonical variables, with variances equal 1 , which are linear combinations of variables that best represent measurement and classification variables (maximum $r$ ).

The classification function coefficients have been determined, and scatterplots of canonical values for pairs of discriminant functions have been drawn for better visualization of performed discrimination. Statistical analyses were performed using Statistica Data Miner v.9 (StatSoft 2009).

Ecological analysis

After differentiation of the three morphological types (corresponding to Lomakin's division (1993)) into the three species Amidostomoides acutum, Amidostomoides monodon, and Amidostomoides petrovi, an ecological analysis of parasite clusters was performed by identifying the following parameters: frequency, prevalence, intensity, relative density, and dominance index. The dominance index (DI) is the only one that completely defines the role of each parasite species in a cluster on the basis of mutual relations between all the indicators:

DI $=P \times H^{+} / H^{2}$,

where:

DI-dominancie index, $P$-number of parasites, $H-$ number of hosts, $H^{+}$-number of infected hosts.

On the basis of its size, three groups of parasites can be distinguished: the dominant species (DI $>1.0)$, subdominant $(0.1<\mathrm{DI}<1.0)$ and rare with $\mathrm{DI}<0.1$ (Margolis et al. 1982; Bush et al. 1997; Kavetska 2006, 2008). For species with DI $>10$, Kavetska (2008) proposed a new term: superdominant.

\section{Results}

Morphometric analysis

The error obtained during the Kohonen neural network learning for 71 males from the examined subfamily was relatively low at 0.1947 . It can be noted that for the species Amidostomoides petrovi, 26 out of 28 observations were grouped in neighboring neurons 6 and 9 , as in the case of Amidostomoides monodon, where 21 of 23 observations were located in neighboring neurons 4 and 7 (Table 1). Neurons 2 and 8 were winning for more than one species and neuron number 5 for none. For the species Amidosto moides acutum, most observations were clustered in neighboring neurons 1 and 3, and neuron 2 was the winner for

Table 1 A topological map with numbered neurons and with assigned labels of Amidostomoides genera species for males and females (in brackets the number of cases activating a given neuron)

\begin{tabular}{|c|c|c|c|c|c|}
\hline \multicolumn{3}{|l|}{ Males } & \multicolumn{3}{|l|}{ Females } \\
\hline 1 & 2 & 3 & 1 & 2 & 3 \\
\hline A. acutum (7) & $\begin{array}{l}\text { A. acutum (3) } \\
\text { A. petrovi (1) } \\
\text { A. monodon (1) }\end{array}$ & A. acutum (10) & $\begin{array}{l}\text { A. acutum (2) } \\
\text { A. petrovi (13) } \\
\text { A. monodon (3) }\end{array}$ & A. monodon (3) & A. monodon (12) \\
\hline 4 & 5 & 6 & 4 & 5 & 6 \\
\hline A. monodon (5) & & A. petrovi (6) & $\begin{array}{l}\text { A. petrovi (11) } \\
\text { A. acutum (1) }\end{array}$ & $\begin{array}{l}\text { A. acutum (2) } \\
\text { A. monodon (1) }\end{array}$ & A. monodon (8) \\
\hline 7 & 8 & 9 & 7 & 8 & 9 \\
\hline A. monodon (16) & $\begin{array}{l}\text { A. monodon (1) } \\
\text { A. petrovi (1) }\end{array}$ & A. petrovi (20) & A. acutum (6) & $\begin{array}{l}\text { A. acutum (4) } \\
\text { A. petrovi (3) }\end{array}$ & $\begin{array}{l}\text { A. acutum (5) } \\
\text { A. petrovi (1) } \\
\text { A. monodon (1) }\end{array}$ \\
\hline
\end{tabular}


three observations. Cases of the species Amidostomoides acutum were slightly worse classified, but all were grouped in the neurons of the upper part of the topological map.

For females, the network learning error was almost twice at 0.3362 , which was reflected in the topological map. As in the case of males, by far the best topology was observed for Amidostomoides petrovi (24 out of 28 observations clustered in two neighboring neurons 1 and 4) and Amidostomoides monodon (20 out of 25 observations grouped in neurons 3 and 6). For the species Amidostomoides acutum there was a greater dispersion of neurons, although 15 of the 20 observations were found in the neurons of the lower layer of the topological map (the remaining five observations were scattered in the neurons of 1, 4, and 5). Similarly, the observation of five species of Amidostomoides monodon were found in neurons 2, 5, and 9, while for Amidostomoides petrovi four observations were found in neurons 8 and 9 .

The analysis confirmed the good discrimination of all three previously distinguished species, both for males and females (Table 2). Amidostomoides monodon was accurately discriminated for both males and females. The group of Amidostomoides acutum was erroneously attributed a single male Amidostomoides petrovi. In the group of females, three specimens of Amidostomoides petrovi were classified to the species Amidostomoides acutum, and one Amidostomoides acutum to Amidostomoides petrovi. However, these individual cases did not materially affect the percentage of accurate classifications (over 95\%).

It should be emphasized that the discrimination of individual species of nematodes was statistically significant (for males $\Lambda=0.0205, F=26.11, p<0.0000$, while for females $\Lambda=0.0280, F=34.11, p<0.0000$ ). Table 3 presents the contributions of the various morphometric variables to the discrimination of the tested species of nematodes. For males, as many as six variables (body length, depth of the buccal capsule and thickness of its wall, the length of the muscular esophagus and the length of the spicule and its proximal part) statistically significantly contribute to the discrimination (high values of $F$ and $p<0.05$ ). In addition, the $\Lambda$ values of these variables are small, which indicates their strong discriminative power, and the value of tolerance coefficients is large (over 0.5), which in turn is an indication that the variables were not redundant.

For females, a statistically significant discriminatory contribution was observed for seven variables: body length, body width at glandular esophagus, width at the root of the tail, thickness of buccal capsule's wall, the length of the muscular esophagus, vulva distance from posterior end, and the length of uterus' posterior part. The $\Lambda$ coefficients of these variables were small, while the coefficients of tolerance were at an acceptable level (from 0.19 to 0.66 ), which also shows a low redundancy in these variables.

The results are confirmed by the scatterplot for canonical values for pairs of discriminant functions (Fig. 1). Individual cases were located in three clusters belonging to the species studied, particularly evidently in the case of males. In females, although three characteristic groups can also be distinguished-Amidostomoides monodon is clearly located on the left of the graph-for the remaining two species the distinction is visible but not as clear.

The nematode is characterized by a relatively large variability within species, which could not be without effect on the strength of discrimination. In males, parameters with the highest rate of variation are the width of the body, the width of bursa copulatrix, the length of the proximal part of spicule, and in females: body width, length of the ovary, and length of uterus' anterior part. The measurements of basic parameters of nematode bodies are presented in Tables 4, 5, and 6 .

It should be emphasized that all previously analyzed variables were purely quantitative. It seems, however, that in the discriminant analysis, qualitative characteristics may, in the case of the nematode subfamily Amidostomatinae, play a more important role. The most important of these include: differences in the shape of buccal capsule (Fig. 2a-c), including the presence of distinct papillae in Amidostomoides petrovi, the shape of the anterior part of the body ("bottle-like" in Amidostomoides acutum and cylindrical in the other two species), the shape and arrangement of postanales papillae in males (Fig. 3a-c), the shape of the proximal part of spicule and its position in relation to its shaft (Fig. $3 \mathrm{~d}-\mathrm{f}$ ), and the shape of the female tail (Fig. 2d-f).
Table 2 Matrix of classification with the percentage of correct classifications for the three analyzed nematode species

\begin{tabular}{|c|c|c|c|c|c|c|c|c|}
\hline \multirow[t]{2}{*}{ Species } & \multicolumn{2}{|c|}{$\begin{array}{l}\text { Correct } \\
\text { classification, \% }\end{array}$} & \multicolumn{2}{|c|}{$\begin{array}{l}\text { Amidostomoides } \\
\text { acutum }\end{array}$} & \multicolumn{2}{|c|}{ A. petrovi } & \multicolumn{2}{|c|}{ A. monodon } \\
\hline & Males & Females & Males & Females & Males & Females & Males & Females \\
\hline $\begin{array}{l}\text { Amidostomoides } \\
\text { acutum }\end{array}$ & 100.00 & 95.00 & 20 & 19 & 0 & 1 & 0 & 0 \\
\hline A. petrovi & 96.43 & 89.29 & 1 & 3 & 27 & 25 & 0 & 0 \\
\hline A. monodon & 100.00 & 100.00 & 0 & 0 & 0 & 0 & 23 & 25 \\
\hline Total & 98.59 & 94.52 & 21 & 22 & 27 & 26 & 23 & 25 \\
\hline
\end{tabular}


Table 3 Wilks lambda coefficient $(\Lambda)$, tolerance coefficient $(T)$, and $F$ with the levels of statistical significance $(p)$

\begin{tabular}{|c|c|c|c|c|c|c|c|c|}
\hline & \multicolumn{2}{|l|}{$\Lambda$} & \multicolumn{2}{|l|}{$T$} & \multicolumn{2}{|l|}{$F$} & \multicolumn{2}{|l|}{$p$} \\
\hline & Males & Females & Males & Females & Males & Females & Males & Females \\
\hline Total length & 0.0317 & 0.0380 & 0.6002 & 0.2144 & 15.3003 & 9.6550 & 0.0000 & 0.0003 \\
\hline Width at buccal capsule & 0.0212 & 0.0293 & 0.8151 & 0.4275 & 1.0122 & 1.2494 & 0.3700 & 0.2948 \\
\hline Width at glandular esophagus & 0.0208 & 0.0339 & 0.5151 & 0.4502 & 0.4277 & 5.6247 & 0.6541 & 0.0060 \\
\hline Width at bursa copulatrix & 0.0207 & & 0.5637 & & 0.3658 & & 0.6953 & \\
\hline Width at tail & & 0.0337 & & 0.5236 & & 5.5016 & & 0.0067 \\
\hline Thickness of buccal capsule's wall & 0.0282 & 0.0331 & 0.7758 & 0.6657 & 10.5501 & 4.8709 & 0.0001 & 0.0114 \\
\hline Depth of buccal capsule & 0.0255 & 0.0289 & 0.7269 & 0.4977 & 6.8690 & 0.8217 & 0.0021 & 0.4451 \\
\hline Length of teeth & 0.0211 & 0.0294 & 0.6074 & 0.6665 & 0.8466 & 1.3772 & 0.4343 & 0.2610 \\
\hline Length of muscular esophagus & 0.0260 & 0.0403 & 0.6865 & 0.3017 & 7.6143 & 11.8779 & 0.0012 & 0.0001 \\
\hline Length of glandular esophagus & 0.0206 & 0.0284 & 0.6457 & 0.9077 & 0.1162 & 0.3531 & 0.8905 & 0.7042 \\
\hline Length of spicule & 0.0237 & - & 0.6490 & - & 4.4233 & - & 0.0165 & - \\
\hline Length of proximal part of spicule & 0.0342 & - & 0.5356 & - & 18.7271 & - & 0.0000 & - \\
\hline Length of gubernaculum & 0.0223 & - & 0.6167 & - & 2.4816 & - & 0.0928 & - \\
\hline Width of bursa copulatrix & 0.0211 & - & 0.5155 & - & 0.8383 & - & 0.4378 & - \\
\hline Vulva distance from posterior end & - & 0.0334 & - & 0.1951 & - & 5.2165 & - & 0.0085 \\
\hline Length of uterus' anterior part & - & 0.0316 & - & 0.3680 & - & 3.4135 & - & 0.0402 \\
\hline Length of uterus' posterior part & - & 0.0310 & - & 0.4356 & - & 2.8580 & - & 0.0661 \\
\hline Length of ovary's anterior part & - & 0.0281 & - & 0.4138 & - & 0.0865 & - & 0.9173 \\
\hline Length of ovary's posterior part & - & 0.0316 & - & 0.2395 & - & 3.4851 & - & 0.0377 \\
\hline Length of tail & - & 0.0299 & - & 0.4705 & - & 1.8019 & - & 0.1748 \\
\hline Length of egg & - & 0.0296 & - & 0.5460 & - & 1.5202 & - & 0.2279 \\
\hline Width of egg & - & 0.0296 & - & 0.6326 & - & 1.4828 & - & 0.2361 \\
\hline
\end{tabular}

Fig. 1 The distribution of canonical variables for males and females of parasitic nematodes
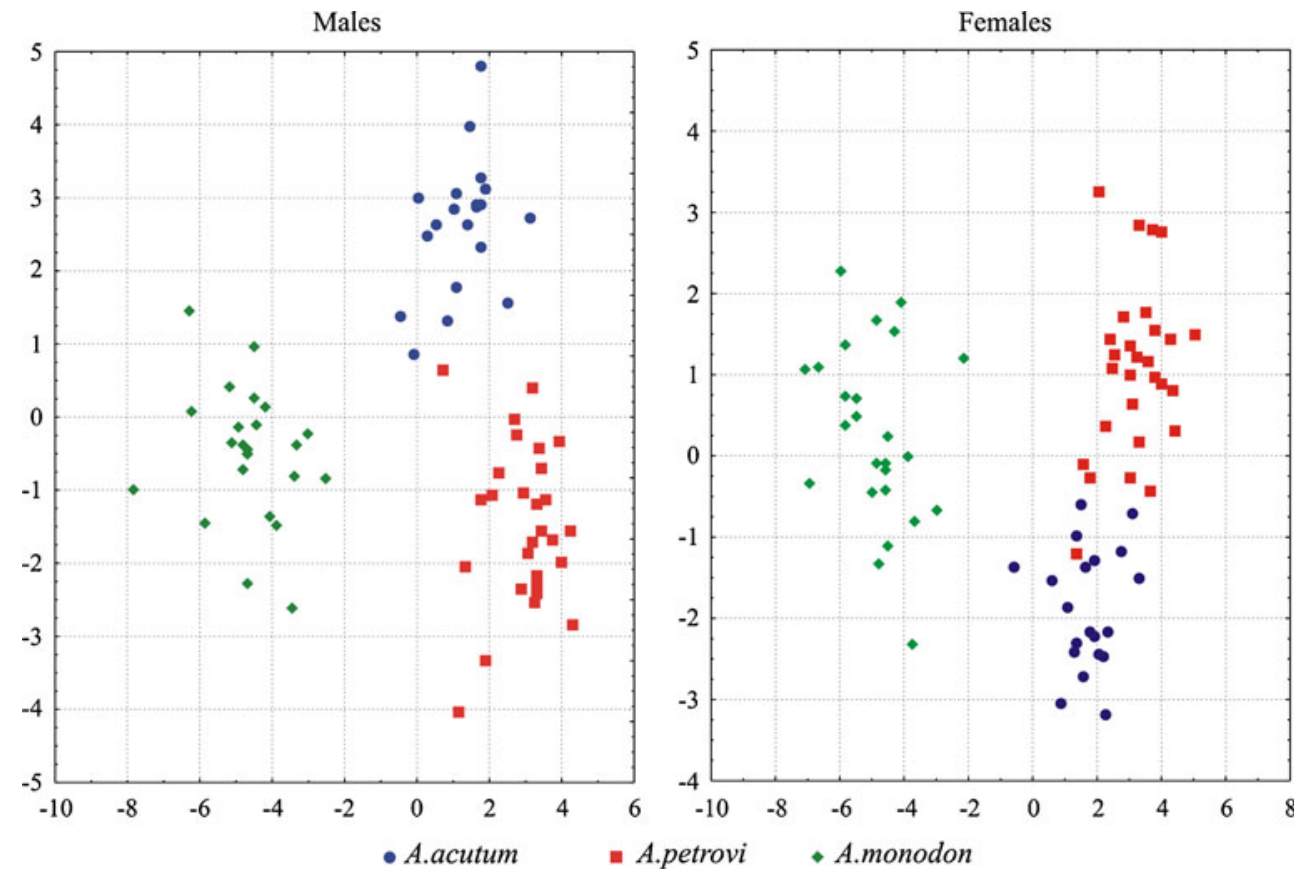


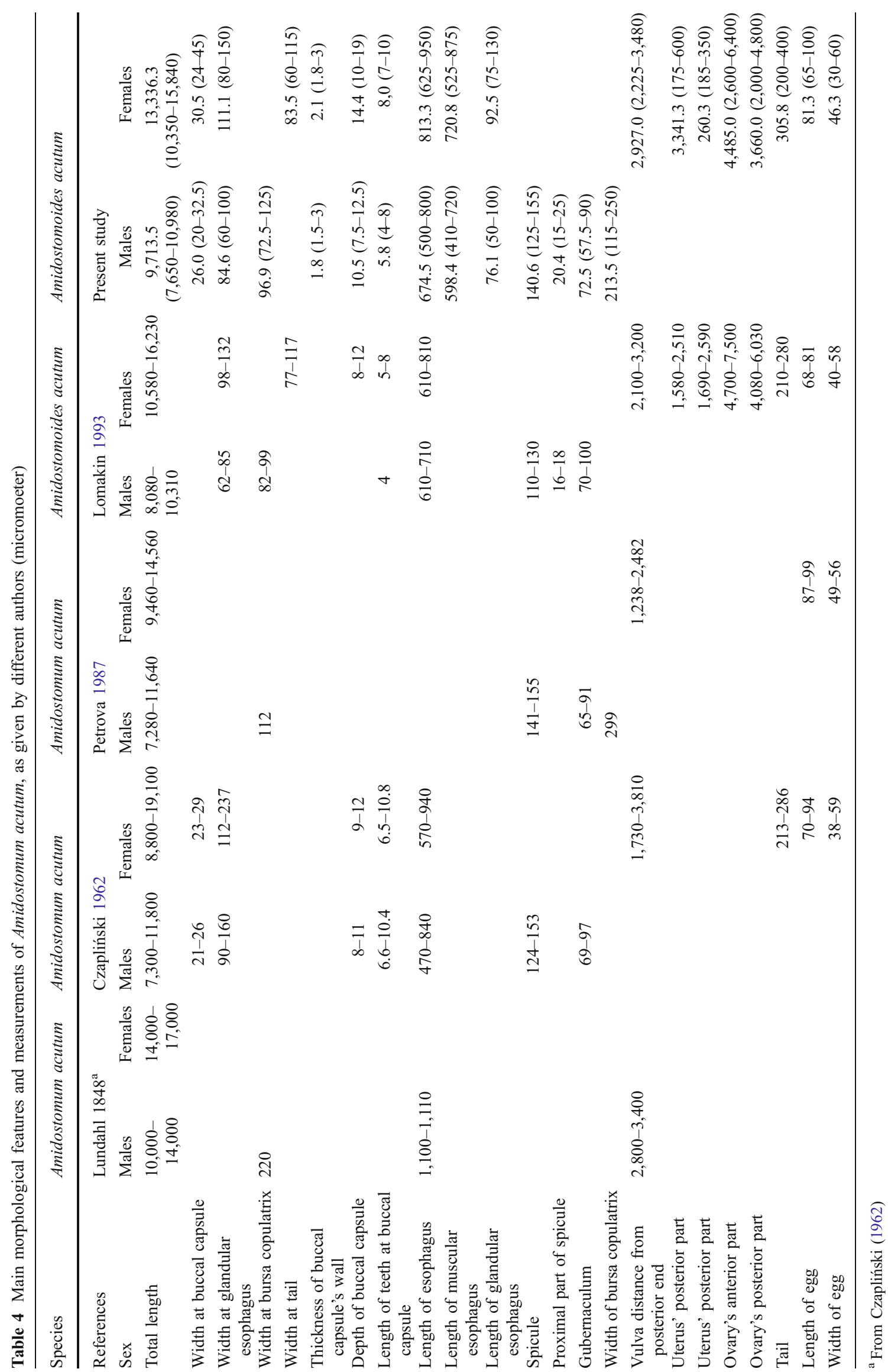


Table 5 Main morphological features and measurements of Amidostomoides petrovi, as given by different authors (micrometers)

\begin{tabular}{|c|c|c|c|c|c|c|}
\hline \multirow{3}{*}{$\begin{array}{l}\text { Species } \\
\text { References } \\
\text { Sex }\end{array}$} & \multicolumn{2}{|c|}{ Amidostomum orientale } & \multicolumn{2}{|c|}{ Amidostomoides petrovi } & \multicolumn{2}{|c|}{ Amidostomoides petrovi } \\
\hline & Rizhikov and $\mathrm{P}$ & avlov $1959^{\mathrm{a}}$ & Lomakin 1993 & & Present study & \\
\hline & Males & Females & Males & Females & Males & Females \\
\hline Total length & $8,900-12,000$ & $12,300-18,300$ & $8,450-10,510$ & $10,120-16,630$ & $\begin{array}{l}7,868.6 \\
(7,020-10,260)\end{array}$ & $\begin{array}{l}11,059.7 \\
\quad(8,478-14,400)\end{array}$ \\
\hline Width at buccal capsule & 20 & 26 & & & $26.1(20-32.4)$ & $29.0(21.6-36)$ \\
\hline Width at glandular esophagus & & & & & $83.6(60-100)$ & $94.6(75-140)$ \\
\hline Width at bursa copulatrix & & & $82-106$ & & $86.1(65-125)$ & \\
\hline Width at tail & & & & $85-120$ & & $65.2(50-85)$ \\
\hline Thickness of buccal capsule's wall & & & & & $2.4(1.8-4.0)$ & $2.7(2-3.6)$ \\
\hline Depth of buccal capsule & $7-10$ & 11 & $9-13$ & $9-13$ & $13.3(10-16)$ & $14.1(9-18)$ \\
\hline Length of teeth at buccal capsule & 7 & & $6-8$ & $6-9$ & $6.0(4-7)$ & $7.0(5-9)$ \\
\hline Length of esophagus & $610-880$ & $710-1,020$ & $580-760$ & $620-940$ & $720.5(600-880)$ & $778.9(500-950)$ \\
\hline Length of muscular esophagus & & & & & $645.5(510-800)$ & $695.0(420-875)$ \\
\hline Length of glandular esophagus & & & & & $75.0(50-95)$ & $84(60-100)$ \\
\hline Spicule & & 132 & $132-153$ & & $123.3(112.5-140)$ & \\
\hline Proximal part of spicule & & & $7-17$ & & $12.8(10-20)$ & \\
\hline Gubernaculum & & 90 & $70-90$ & & $58.0(40-75)$ & \\
\hline Width of bursa copulatrix & & & & & $200.0(160-240)$ & \\
\hline Vulva distance from posterior end & & $2,500-3,500$ & & $2,150-2,990$ & & $2,429.3(1,875-3,425)$ \\
\hline Uterus' posterior part & & & & $1,830-3,070$ & & $265.5(185-350)$ \\
\hline Uterus' posterior part & & & & $1,530-2,340$ & & $220.0(175-310)$ \\
\hline Ovary' anterior part & & & & $5,310-8,810$ & & $3,342.9(2,400-6,400)$ \\
\hline Ovary's posterior part & & & & $5,010-7,270$ & & $2,506.8(1,600-4,700)$ \\
\hline Tail & & $270-340$ & & $230-310$ & & $293.9(225-350)$ \\
\hline Length of egg & & $77-84$ & & $73-91$ & & $81.6(70-95)$ \\
\hline Width of egg & & $42-49$ & & $40-58$ & & $47.1(40-55)$ \\
\hline
\end{tabular}

${ }^{\text {a }}$ From Czapliński (1962)

Ecological analysis

Thirteen thousand three hundred and thirty-three nematodes were isolated from the digestive systems of the surveyed ducks. The Amidostomatinae subfamily was represented by 6,430 individuals. Morphological analysis, supported by the results of discriminant and unsupervised analyses, indicates that the nematodes from this subfamily were represented by three species: Amidostomoides acutum (Lundahl, 1848) Lomakin 1991 ( $n=550)$, Amidostomoides petrovi (Shakhtahtinskaya 1956) Lomakin $1991(n=1,167)$ and Amidostomoides monodon (Linstow, 1882) Lomakin $1991(n=4,713)$.

All the nematodes were characterized by distinct host specificity: Amidostomoides acutum was observed only in ducks of the tribe Anatini (Anas penelope and Anascrecca, Anas platyrhynchos, Anas querquedula, Anas clypeata), Amidostomoides petrovi in Aythyini (Aythya ferina, Aythya fuligula, and Aythya marila) and in Bucephala clangula (Mergini), while Amidostomoides monodon was found only in Mergini (Somateria mollissima, Clangula hyemalis, Melanitta nigra, Melanitta fusca, Mergus merganser).
Parasites occurred only in the gizzard muscle, with a characteristic separation of the habitats: Amidostomoides acutum was located under the soft, mucous layer of the gizzard inlet (98.7\% of parasites), Amidostomoides monodon under the hardest part of the chitinous layer in the middle section of the gizzard (87.7\%), and Amidostomoides petrovi - both in the inlet and pyloric part of gizzard ( $85.9 \%$ parasites), bypassing the central part of the gizzard muscle. One more regularity was observed. Nematodes Amidostomoides acutum and Amidostomoides petrovi were positioned straight or as a gently curved sinusoid, and Amidostomoides monodon almost always occurred as a quite strongly curled ball.

Basic characteristics of the three nematode species from the genus Amidostomoides are shown in Table 7. Nematodes from this taxon were found in 587 out of 1,005 examined ducks $(58.4 \%)$, with the average intensity from one to 207 parasites (mean, 10.9). The relative density reached 6.4, while the coefficient of dominance was 3.737, which clearly puts these parasites in the group of dominants $(\mathrm{DI} \geq 1)$. The dominance index for each species of parasites was somewhat different. While the DI values for Amidostomoides acutum and Amidostomoides petrovi were very 
Table 6 Main morphological features and measurements of Amidostomoides monodon, as given by different authors (micrometers)

\begin{tabular}{|c|c|c|c|c|}
\hline \multirow{3}{*}{$\begin{array}{l}\text { Species } \\
\text { References } \\
\text { Sex }\end{array}$} & \multicolumn{2}{|c|}{ Amidostomoides monodon } & \multicolumn{2}{|l|}{ Amidostomoides monodon } \\
\hline & \multicolumn{2}{|l|}{ Lomakin 1993} & \multicolumn{2}{|l|}{ Present study } \\
\hline & Males & Females & Males & Females \\
\hline Total & $11,120-13,390$ & $14,630-18,080$ & $12,580.0(10,000-14,760)$ & $15,830.7(13,410-19,260)$ \\
\hline Width at buccal capsule & & & $30.5(25-38)$ & $32.3(25-40.0)$ \\
\hline Width at glandular esophagus & & & $101.5(75-125)$ & $104.5(70-140)$ \\
\hline Width at bursa copulatrix & $110-130$ & & $109.0(75-150)$ & \\
\hline Width at tail & & $100-140$ & & $82.7(70-115)$ \\
\hline Thickness of buccal capsule's wall & & & $3.2(2.5-5)$ & $3.4(2-6)$ \\
\hline Depth of buccal capsule & $9-13$ & $10-13$ & $14.7(10-20)$ & $14.9(10-18)$ \\
\hline Length of teeth at buccal capsule & $6-8$ & $6-9$ & $7.8(5-10)$ & $8.0(6-10)$ \\
\hline Length of esophagus & $630-760$ & $700-840$ & $718.9(650-800)$ & $764.4(675-850)$ \\
\hline Length of muscular esophagus & & & $621.1(465-710)$ & $664.2(590-750)$ \\
\hline Length of glandular esophagus & & & $98.9(75-125)$ & $100.2(75-150)$ \\
\hline Spicule & $141-167$ & & $156.6(145-180)$ & \\
\hline Proximal part of spicule & $13-18$ & & $18.7(10-25)$ & \\
\hline Gubernaculum & $70-90$ & & $83.2(50-110)$ & \\
\hline Width of bursa copulatrix & & & $253.0(180-350)$ & \\
\hline Vulva distance from posterior end & & $3,210-4,300$ & & $3,709.0(2,770-4,350)$ \\
\hline Uterus' posterior part & & $2,180-3,500$ & & $499.4(300-700)$ \\
\hline Uterus' posterior part & & $2,940-3,550$ & & $485.0(250-650)$ \\
\hline Ovary' anterior part & & $5,470-8,170$ & & $5,552.0(3,600-7,900)$ \\
\hline Ovary's posterior part & & $6,620-8,930$ & & $4,192.0(2,400-5,500)$ \\
\hline Tail & & $266-366$ & & $325.0(275-375)$ \\
\hline Length of egg & & $86-98$ & & $100.4(80-110)$ \\
\hline Width of egg & & $47-60$ & & $56.5(50-75)$ \\
\hline
\end{tabular}

close (1.401 and 1.421, respectively), Amidostomoides monodon reached a value as high as 9.111. The case of eider was particularly noteworthy, being especially heavily infected by Amidostomoides monodon (mean intensity, relative density, and the dominance index were as high as 142.0). This parasite was superdominant in black scoter $(\mathrm{DI}=27.503)$, and dominant in white-winged scoter and the long-tailed duck (DI at 5.165 and 3.640, respectively). One specimen out of the 60 surveyed Common mergansers was quite unusual in this context, with only three specimens of Amidostomoides monodon. It can be assumed that this parasite does not belong to its helminthofauna, and perhaps merganser was an accidental host for Amidostomoides monodon.

The nematodes from the examined genera were not found in three species of duck-Anatini (Anas strepera) and Mergini tribe (Mergellus albellus and Mergus serrator). Perhaps their absence is a characteristic feature of these hosts. However, due to the small number of studied species of these birds (five in total), further research in this field is recommended.

\section{Discussion}

Morphological analysis

Amidostomoides acutum (Lundahl, 1848) Lomakin 1991

The first description of this species was performed by Lundahl in 1848 and contained very little information on the morphology and hosts of the parasite (Lomakin 1993). Subsequent reports by different authors (Diesing, 1861; Molin, 1860; Seurat, 1918; Cram, 1927; Travassos, 1937 et al.) also did not provide much information, as these researchers were only citing earlier descriptions of the parasite.

The first exact description of the species was given by Czaplinski as late as 1962. The author, relying on the morphology of nematodes from birds of Poland, France, and East Africa, used the synonym Amidostomum acutum for eight species with a single tooth in the buccal capsule: Amidostomoides monodon (Linstow, 1882), Amidostomum chevreuxi Seurat, 1918, Amidostomum skrjabini Boulenger, 1926, 
Fig. 2 The most important qualitative elements differentiating Amidostomoides nematodes. Anterior end, ventral view: a Amidostomoides acutum, $\mathbf{b}$ Amidostomoides monodon, $\mathbf{c}$ Amidostomoides petrovi. Scale bar: $15 \mu \mathrm{m}$ a)

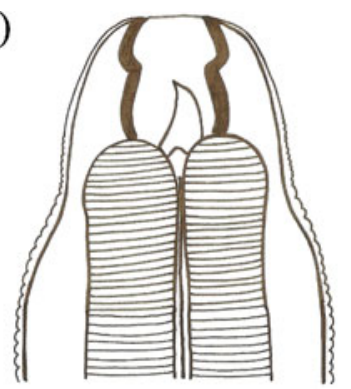

d)

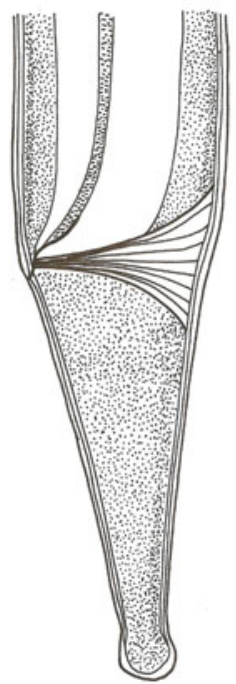

b)

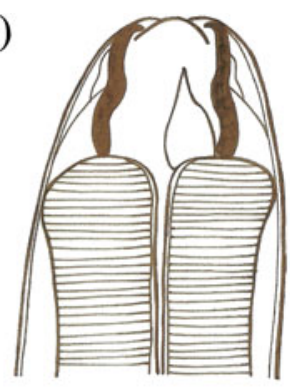

e)

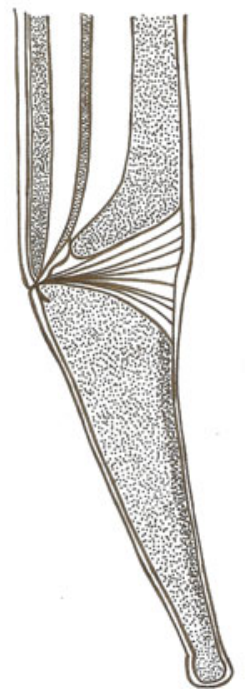

c)

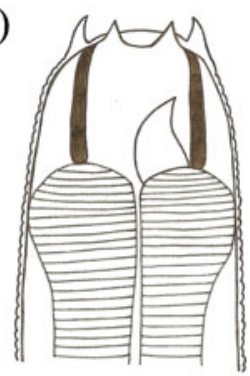

f)

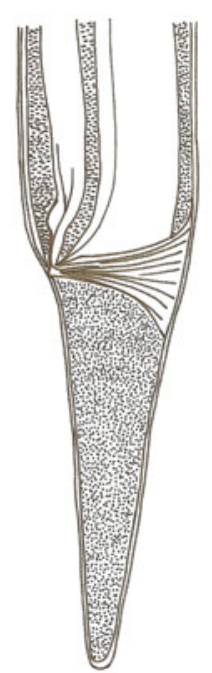

Fig. 3 Amidostomoides petrovi, posterior end of male with the location of postcloacal papillae. Scale bar: $60 \mu \mathrm{m}$. Different forms of postcloacal papillae, spicules, proximal part of spicule and gubernaculum: a $\mathrm{Ami}$ dostomoides acutum, $\mathbf{b}$ Amidostomoides monodon, $\mathbf{c}$ Amidostomoides petrovi. Scale bar: $10 \mu \mathrm{m}$

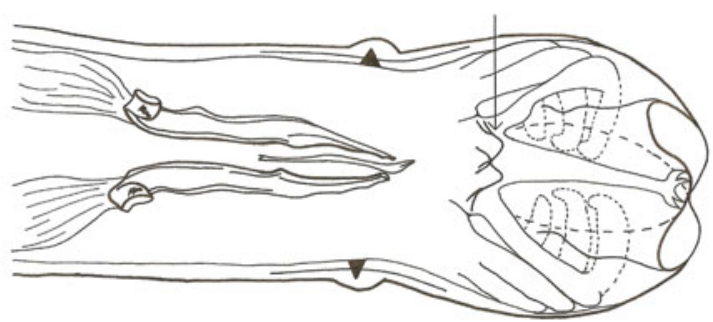

a)
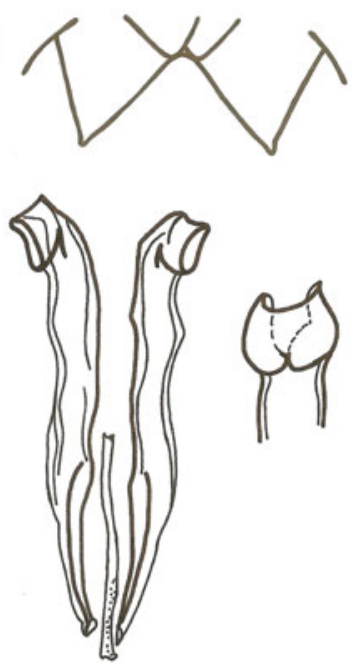

b)<smiles>CC1CCCC1(C)C1CCCC1</smiles>

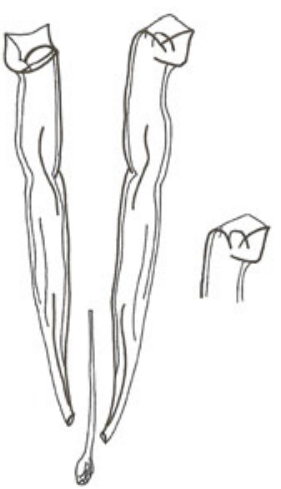

c)
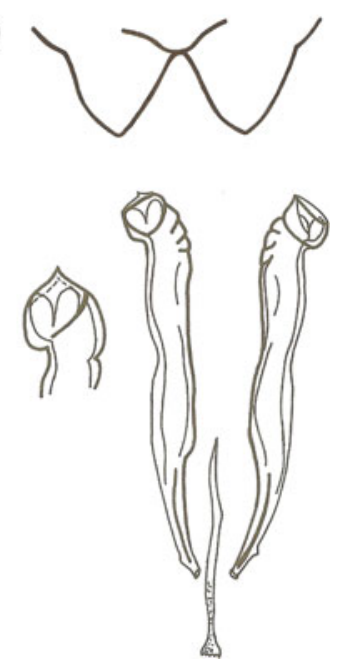
Table 7 Characteristic of the nematodes from the genus Amidostomoides found in the Anatinae from north-western Poland

\begin{tabular}{|c|c|c|c|c|c|c|c|c|c|}
\hline \multirow[t]{2}{*}{ Hosts } & \multirow[t]{2}{*}{ Parasite } & \multirow[t]{2}{*}{ Frequency } & \multicolumn{2}{|c|}{ Prevalence } & \multirow[t]{2}{*}{ Mode } & \multicolumn{2}{|l|}{ Intensity } & \multirow[t]{2}{*}{ Relative density } & \multirow[t]{2}{*}{ Dominance } \\
\hline & & & $n$ & $\%$ & & Range & Mean & & \\
\hline Anatini, $n=225$ & & 550 & 129 & 57.3 & & $1-24$ & 4.3 & 2.4 & 1.401 \\
\hline Anas penelope, $n=2$ & A. acutum & 1 & 1 & 50.0 & - & 1 & 1.0 & 0.5 & 0.500 \\
\hline A. strepera, $n=2$ & - & - & - & - & - & - & - & - & - \\
\hline A. $\operatorname{crecc} a, n=11$ & A. acutum & 16 & 6 & 54.5 & 1 & $1-6$ & 2.7 & 1.5 & 0.793 \\
\hline A. platyrhynchos, $n=204$ & A. acutum & 516 & 120 & 58.8 & 1 & $1-24$ & 4.3 & 2.5 & 1.488 \\
\hline A. querquedula, $n=1$ & A. acutum & 9 & 1 & 100.0 & - & 9 & 9.0 & 9.0 & 9.000 \\
\hline A. clypeata, $n=5$ & A. acutum & 8 & 1 & 20.0 & - & 8 & 8.0 & 1.6 & 0.320 \\
\hline Aythyini, $n=413$ & & 1,076 & 222 & 53.7 & & $1-31$ & 4.8 & 2.6 & 1.400 \\
\hline Aythya ferina, $n=20$ & A. petrovi & 11 & 7 & 35.0 & 1 & $1-3$ & 1.6 & 0.6 & 0.193 \\
\hline A. fuligula, $n=236$ & A. petrovi & 428 & 119 & 50.4 & 1 & $1-15$ & 3.6 & 0.5 & 0.914 \\
\hline A. marila, $n=157$ & A. petrovi & 637 & 96 & 61.2 & 1 & $1-31$ & 6.6 & 4.1 & 2.481 \\
\hline Mergini, $n=367$ & & 4,804 & 236 & 64.3 & & $1-207$ & 20.3 & 13.1 & 8.417 \\
\hline Somateria mollissima, $n=4$ & A. monodon & 568 & 4 & 100.0 & - & 26-207 & 142.0 & 142.0 & 142.000 \\
\hline Clangula hyemalis, $n=112$ & A. monodon & 593 & 77 & 68.8 & 3 & $1-84$ & 7.7 & 5.3 & 3.640 \\
\hline Melanitta fusca, $n=48$ & A. monodon & 340 & 35 & 72.9 & 4 & $1-36$ & 9.7 & 7.1 & 5.165 \\
\hline M. nigra, $n=108$ & A. monodon & 3,208 & 100 & 92.6 & 1 & $1-185$ & 32.1 & 29.7 & 27.503 \\
\hline Bucephala clangula, $n=32$ & A. petrovi & 92 & 19 & 59.4 & 1 & $1-19$ & 4.8 & 2.9 & 1.707 \\
\hline Mergellus albellus, $n=1$ & - & - & - & - & - & - & - & - & - \\
\hline Mergus merganser, $n=60$ & A. monodon & 3 & 1 & 1.7 & - & 3 & 3.0 & 0.05 & 0.001 \\
\hline M. serrator, $n=2$ & - & - & - & - & - & - & - & - & - \\
\hline Total, $n=1,005$ & & 6,430 & 587 & 58.4 & 1 & $1-207$ & 10.9 & 6.4 & 3.737 \\
\hline
\end{tabular}

Amidostomum anatinum Sugimoto 1928, Amidostomum fuligulae Maplestone 1930, Amidostomum biziurae Johnston et Mawson 1947, Amidostomum boshadis Petrov et Fedushin 1949, and Amidostomum orientale Rijikov et Pavlov 1959. A few years later Kobuley and Ryzhikov (1968) performed a reanalysis of these nine species from "acutum" group and recognized the validity of three of them: Amidostomoides monodon, Amidostomoides orientale, and Amidostomoides cheuvreuxi. Another morphological analysis of this group was performed by Lomakin (1993), and on the basis of morphological differences, he distinguished three separate speciesAmidostomoides monodon, Amidostomoides orientale, and Amidostomoides biziurae, treating Amidostomoides cheuvreuxi as a synonym for Amidostomoides acutum.

\section{Amidostomoides monodon (Linstow, 1882) Lomakin 1991}

The first description of this species by Linstow in 1882 was based on one female derived from the gizzard of Melanitta fusca. According to Lomakin (1993), it was as late as 1915 when Skrjabin 1915 supplemented the data by Linstow with a description of a male from the same host species (Lomakin 1993). Both descriptions, although very modest, have been used in the descriptions of this species in later reviews (Cram 1927, Baylis 1932, 1937). It can be assumed that the lack of a complete morphological characterization of the species was the basis for its inclusion into synonyms of Amidostomum acutum by Czapliński (1962). The first accurate description of this parasite, coming from ducks of the Mergini tribe in Kamchatka and Chukotka, was provided by Ryzhikov (1963a, b), who later, in a joint work with Kobuley (Kobuley and Ryzhikov 1968) demonstrated the distinctness of this species. Lomakin (1993), studying material coming from Mergini in eastern Russia, also confirmed the distinctiveness of Amidostomoides monodon.

\section{Amidostomoides petrovi (Shakhtahtinskaya 1956) Lomakin 1991}

The classification of Amidostomoides orientale to synonyms of Amidostomum acutum by Czapliński (1962) was protested by Kobuley and Ryzhikov (1968), drawing attention to the characteristic feature of this nematode - the presence of relatively long papillae protruding above buccal capsule (Fig. 2c). According to Lomakin (1993), the independence of the species Amidostomoides orientale (except the aforementioned papillae) is also suggested by clear differences in the structure of spicules.

The species Amidostomum petrovi was first described by Shakhtahtinskaya (1956). Nematodes were taken from two 
bird species, order Charadriformes: avocet (Recurvirostra avosetta) and snipe (Common snipe) Gallinago gallinago. That nematode was described very schematically showing no characteristic morphological properties, and discriminant diagnosis was made by the author only on the basis of differences in body size, spicules, gubernaculum, and eggs. The diagnosis included very serious errors (e.g. due to the lack of spicules and gubernaculum in Amidostomum acutum, and the tooth in the buccal capsule of Quasiamidostomum fulicae). However, a drawing by Shakhtahtinskaya presents the front of the nematode body (1956) to have four long conical papillae around the mouth, which according to Lomakin (1993) is a sufficient basis to consider both the species Amidostomoides orientale Rijikov et Pavlov, 1959 and Amidostomoides petrovi Shakhtahtinskaya 1956 as synonyms, and the differences between them may, according to Kobuley and Ryzhikov (1968), be caused by Amidostomoides petrovi parasitizing in hosts unusual for this nematode.

A work by Petrova (1987) was very important for the Amidostomatinae subfamily systematics. The author analyzed the morphological differences and host specificity of 110 specimens of genus Amidostomum, and noted the need to separate it into two subtypes: first (with three teeth in a deep buccal capsule) she proposed to leave the name Amidostomum, and for the second (with one tooth in a shallow buccal capsule) the name Amidostomoides. Accordingly, the subgenus Amidostomum (Amidostomoides) included: A. (A.)acutum (Lundahl, 1848), and A. (A.) quasifulicae (Mačko 1966) and $A$. (A.) fulicae (Rud., 1819); and in the subgenus Amidostomum (Amidostomum): A. (A.) anseris (Zeder, 1800), A. (A.) spatulatum Baylis, 1932, and A. (A.) cygni Wehr, 1933. Based on the suggestion by Petrova (1987), Lomakin (1993) proposed that both subgenera, Amidostomum and Amidostomoides, should be elevated to the rank of genus, leaving their names in accordance with Petrova's proposals. In his works, Lomakin (1991, 1993), as a species typical of the genus Amidostomoides Petrova 1987, described Amidostomoides acutum (Lundahl, 1848) Petrova 1987, and as others mentioned: Amidostomoides monodon (Linstow, 1882) nov. comb, Amidostomoides auriculatum (Lomakin, 1988) and Amidostomoides petrovi (Shakhtahtinskaya 1956) nov. Comb. Despite significant research reports from Bulgaria and Russia, in world literature (but mainly in western English language), two species Amidostomoides petrovi and Amidostomoides monodon, are still disputed as synonyms of Amidostomum acutum.

Unsupervised classification, carried out using a Kohonen artificial neural network, clearly identified three groups of nematodes, in principle overlapping with the proposed division into three species (both for males and females). In particular the species Amidostomoides monodon were a clearly distinct cluster, both males and females. However, the other two species (Amidostomoides petrovi and Amidostomoides acu- tum) were also morfometrically distinct. The analysis of discrimination helped accurately assign observations to the proposed three species of nematodes (ideally in the case of Amidostomoides monodon and with minor exceptions to Amidostomoides petrovi and Amidostomoides acutum). It seems, thereore, that after taking into account the qualitative characteristics of nematodes that were not taken into account in the network and discriminant analyses, one can almost perfectly distinguish these three species.

\section{Ecological analysis}

According to the theory of long-term interactions, a given parasite species cannot infest certain populations of some host species or even some individuals of its population, because the formation of a parasite-host system requires both parasite and host to coexist, meet, accept, and allow to be accepted (Combes 1999). The concept of mechanisms responsible for limiting the range of hosts by using screens implies the selection in the parasite genome and in the host genome. The selection takes place at the level of two filters/ screens: a meeting screen (meeting genes and avoidance genes) and match filter (killing genes and survival genes). Each of these filters is a "hybrid phenotype", encoded by genes belonging to the genome of the parasite and the host genome. The theory of long-term interactions (Combes 1999) can be successfully applied in this study. Strict host specificity of parasites from the subfamily Anatinae suggests far-reaching adaptation in the genome of both parasites and their hosts, which demonstrates the specieslevel distinctness of the studied groups.

Species Amidostomoides acutum is observed only in ducks (Anatini) that are generally associated with freshwater water bodies. These ducks feed on mixed food, collected by submerging the head, neck, and the front part of their body, while lifting the rump. Amidostomoides petrovi is associated with diving ducks (Aythyini) and goldeneyes (Mergini). Diving ducks dive underwater in search for food and feed mostly on plants and small freshwater animals. The diet of goldeneyes, like that of the diving ducks, comprises mostly small freshwater invertebrates (molluscs and aquatic insects). Amidostomoides monodon parasites in marine ducks (Mergini) feeding on animal food (clams, crustaceans, echinoderms), occasionally supplemented by plants. The diet of Common mergansers is quite different. This bird from the Mergini tribe, living in freshwater lakes, feeds almost exclusively on fish. Perhaps this specific diet is the cause of the absence of Amidostomatinae nematodes in its helminthofauna.

According to Lomakin (1993), the hosts of Amidostomoides acutum can not only be Anatini ducks, but also Aythyini and Mergini, and representatives of other orders: Common coot (Fulica atra), Common stilt (Himantopus 
himantopus), Hazel grouse (Tetrastes bonasia), Western capercaillie (Tetrao urogallus), Willow grouse (Lagopus lagopus), and Rock ptarmigan (L. mutus).

All the aforementioned elements, with respect to morphology and ecology of the parasites, confirm the hypothesis of a species-level diversity. However, the final and definite answer may be given only by the use of PCR and RFLP, and DNA sequencing that will allow to the determination of the genetic relationship of the three groups of nematode species from the species complex Amidostomum acutum (Lundahl, 1848).

\section{Conclusion}

Three groups of parasitic nematodes can be found in wild ducks of the subfamily Anatinae. These groups should be treated as three separate species: Amidostomoides acutum (Lundahl, 1848) Lomakin 1991, Amidostomoides monodon (Linstow, 1882) Lomakin 1991, and Amidostomoides petrovi (Shakhtahtinskaya 1956) Lomakin 1991, while Amidostomum acutum (Lundahl, 1848) must be regarded as a species complex.

These species statistically significantly differ in their morphology (qualitative and quantitative traits) and ecology (they have different hosts from different trophic groups).

Open Access This article is distributed under the terms of the Creative Commons Attribution Noncommercial License which permits any noncommercial use, distribution, and reproduction in any medium, provided the original author(s) and source are credited.

\section{References}

Atkinson CT, Thomas NJ, Hunter DB (2008) Parasitic diseases of wild birds. Wiley-Blackwell, London

Anderson RC (2000) Nematode parasites of vertebrates. Their development and transmission. CABI Publishing, Wallingford

Baruš V, Sergejeva TP, Sonin MD, Ryzhikov KM (1978) Helminths of fish-eating birds of the Palaearctic region. I. Nematoda. USSR Academy of Sciences. Helminthological Laboratory Czechoslovak Academy of Sciences. Institute of Parasitology, Moscow

Borgsteede FHM, Okulewicz A, Zoun PEF, Okulewicz J (2005) The gastrointestinal helminth fauna of the Eider duck (Somateria mollissima L.) in the Netherlands. Helminthologia 42:83-87

Borgsteede FHM, Kavetska KM, Zoun PEF (2006) Species of the nematode genus Amidostomum Railliet and Henry, 1909 in birds in the Netherlands. Helminthologia 43:98-102

Bush AO, Lotz LKD, JM SAW (1997) Parasitology meets ecology on its own terms: Margolis et al. revisited. J Parasitol 83:575-583

Combes C (1999) Interactions durables. Ecologie et évolution du parasitisme. PWN, Warszawa
Czapliński B (1962) Nematodes and acanthocephalans of domestic and wild Anseriformes in Poland. I. Revision of the genus Amidostomum Railliet et Henry, 1909. Acta Parasitol Pol 10:125164

Haykin S (2009) Neural networks and learning machines. Pearson International Editon, pp 456-465

Kats RKH (2007) Common Eiders Somateria mollissima in the Netherlands: the rise and fall of breeding and wintering populations in relation to stocks of shellfish. Dissertations, University of Groningen

Kavetska KM (2005a) The intestinal nematodes of wild ducks (Anatinae) from north-west region of Poland. Wiad Parazytol $51: 57-158$

Kavetska KM (2005b) Intestinal nematodes of the Aythyini ducks in Western Pomerania. Wiad Parazytol 51:157-163

Kavetska KM (2005c) Nematode fauna of the Mergini (Anatinae) ducks in north-western part of Poland. Vestn Zool 19:160 161

Kavetska KM (2006) Biological and ecological background of nematode fauna structure formation in the alimentary tracts of wild Anatinae ducks in north-western Poland. Dissertations, Agricultural University in Szczecin

Kavetska KM (2008) Nematofauna of ducks of the genus Melanitta (Mergini, Anseriformes) from the south Baltic Sea. Wiad Parazytol 54:155-157

Kavetska KM, Rząd I, Kornyushin VV, Korol EN, Sitko J, Szałańska K (2008a) Enteric helminths of the mallard Anas platyrhynchos L., 1758 in the north-western part of Poland. Wiad Parazytol 54:23-29

Kavetska KM, Szałańska K, Kalisińska E, Kornyushin VV, Korol EN (2008b) Helminthofauna of the goosander Mergus merganser L., 1758 from the north-western Poland. Wiad Parazytol 54:325330

Kobuley T, Ryzhikov KM (1968) Characteristics of the genus Amidostomum (Nematoda: Strongylata). Parazitologiâ 4:306-311

Kohonen T (1989) Self-organization and associative memory. Springer Verlag, Berlin

Lomakin VV (1991) Revision of family Amidostomatidae (Nematoda, Strongylida). Gelm Živ 38:70-85

Lomakin VV (1993) Revision of subfamily Amidostomatinae Travassos, 1919 (Amidostomatidae, Strongylida). Problems of morphology, ecology and physiology of helminths. Trudy Gelmint Lab 92122

Mačko JK (1966) Amidostomum quasifulicae sp. nov. (Nematoda: Strongylata) from Gallinula chloropus. Annot Zool Bot 28:16

Margolis L, Esch GW, Holmes JC, Kuris AM, Schad GA (1982) The use of ecological terms in parasitology (report of an ad hoc committee of the American Society of Parasitologists). J Parasitol 68:131-133

Morrison DF (1990) Multivariate statistical methods. PWN 329, Warsaw

Osowski S (1996) Neuron networks in the algorythmic approach. WN-T, Warsaw

Petrova K (1987) Species composition of nematodes from the genus Amidostomum Railliet et Henry, 1909 (Strongylata: Amidostomatidae) in Bulgaria. Helminthologia 24:53-72

Pojmańska T, Niewiadomska K, Okulewicz A (2007) Parasitic helminths in Poland. Species, hosts, Terra Incognita. Polish Parasitological Society, Warszawa

Ryšav B, Groschaft J, Baruš V, Dvořaková L (1982) Helminths of water birds. Československé akademie věd, Praha

Ryzhikov KM (1963a) Helminthofauna of wild and domestic Anseriformes in the Far East. Tr Gelmint Lab 13:78-132

Ryzhikov KM (1963b) /Nematodes of Anseriformes birds from Kamcatka. Tr Gelmint Lab 13:133-143 
Samarasinghe S (2006) Neural networks for applied science and engineering. from fundamentals to complex pattern recognition. Auerbacg Publications pp 337-437

Shakhtahtinskaya ZM (1956) Two new species of nematodes in Azerbaijan. Dokl AN AzSSR 12:37-41

StatSoft, Inc. (2009) STATISTICA (data analysis software system), version 9.0. www.statsoft.com

Statistica Neural Network (1998) User manual. Quik feference. StatSoft Inc, Tulsa
Thieltges DW, Hussel B, Baekgaard H (2006) Endoparasites in common eider Somateria mollissima - an unbiased sample from birds killed by an oil spill in the Wadden Sea. J Sea Res 55:301308

Zajiček D (1964) The embryonal and postembryonal development of Amidostomum boschadis Petrow and Fadiuchin, 1949 (Nematoda). In: Ergens et Ryšavy B (eds) Parasitic worms and aquatic conditions. Proc of symp, Praque, October 29th November 2nd: 137-143. http://www.faunaeur.org/ 